\title{
Pencirian dan Pembezaan Osteogenik Sel Stem Pulpa Gigi Kekal dan Gigi Desiduos Manusia
}

(Characterization and Osteogenic Differentiation of Human Dental Pulp Stem Cells and Stem Cells from Exfoliated Deciduous Teeth)

\author{
FARINAWATI YAZID, NUR ATMALIYA LUCHMAN, ROHAYA MEGAT ABDUL WAHAB \\ \& SHAHRUL HISHAM ZAINAL ARIFFIN*
}

\begin{abstract}
ABSTRAK
Sel stem pulpa gigi daripada gigi kekal (DPSC) dan gigi desiduos (SHED) merupakan sel stem mesenkima dewasa yang mudah diperoleh dan berpotensi di dalam terapi sel. Pengasingan sel ini melibatkan pendekatan yang kurang invasif. Pencirian dan potensi pembezaan osteogenik bagi DPSC dan SHED adalah penting untuk memanipulasi sel ini bagi tujuan perubatan regeneratif. Tujuan kajian ini adalah untuk pencirian dan pengenalpastian potensi osteogenik bagi sel stem dewasa yang diasingkan daripada tisu pulpa gigi kekal dan gigi desiduos manusia. Pulpa gigi dipencilkan daripada gigi kekal dan gigi desiduos manusia menggunakan kaedah pencernaan enzim dan seterusnya dikulturkan sehingga pasaj 3. Morfologi sel dikenal pasti menggunakan perisian CellB. Kadar proliferasi DPSC dan SHED pula ditentukan menggunakan pengasaian tiazolilbiru tetrazolium bromida (MTT). Sementara itu, potensi pembezaan osteoblas bagi DPSC dan SHED ditentukan menggunakan analisis biokimia. Hasilnya, kedua-dua jenis sel ini menunjukkan morfologi menyerupai sel fibroblas pada pasaj 3. Kadar proliferasi SHED pula menunjukkan secara signifikan (p<0.05) ia jauh lebih tinggi berbanding DPSC. Kajian ini turut menunjukkan bahawa aktiviti alkali fosfatase (ALP) bagi SHED adalah secara signifikannya lebih tinggi berbanding dengan DPSC ( $\mathrm{p}<0.05)$ apabila dikulturkan di dalam medium pembezaan osteoblas . Kesimpulannya, DPSC dan SHED mampu untuk membahagi dan membeza kepada osteoblas. Walau bagaimanapun, SHED telah menunjukkan kadar proliferasi serta potensi osteogenik yang lebih tinggi berbanding DPSC.
\end{abstract}

Kata kunci: Fibroblas; pembezaan osteoblas; proliferasi; pulpa gigi; sel stem mesenkima

ABSTRACT

Dental pulp stem cells from permanent (DPSC) and deciduous teeth (Stem Cells from Human Exfoliated Deciduous Teeth; SHED) are adult mesenchymal stem cells that are easily available for cellular therapy. Isolation of these cells acquired less invasive approached. The characterization and osteogenic differentiation potential of the DPSC and SHED are important in manipulating these cells for regenerative medicine purpose. This study aims to characterize and determine the osteogenic potential of adult stem cells isolated from the permanent and deciduous dental pulp tissues. Dental pulp was extracted from human permanent and deciduous teeth using an enzymatic digestion method and cells were cultured until passage 3. Cell morphology was determined with CellB software. The proliferation rate of DPSC and SHED were assessed by 3-(4,5-dimethylthiazol-2-yl)-2,5-diphenyltetrazolium (MTT) assay. Meanwhile, the osteoblast differentiation potential of DPSC and SHED were determined by biochemical analysis. Both types of cells exhibited fibroblast-like morphology at passage 3. The proliferation rate of SHED was significantly higher $(\mathrm{p}<0.05)$ than DPSC. This study also showed that the osteoblast differentiation using alkaline phosphatase $(A L P)$ activity was significantly higher $(\mathrm{p}<0.05)$ in SHED compared to DPSC. In conclusion, both cells are capable of proliferating and differentiating into osteoblast where SHED showed higher proliferating rate and osteogenic potential as compared to DPSC.

Keywords: Dental pulp; fibroblast-liked; mesenchymal stem cells; osteoblast differentiation; proliferation

\section{PENDAHULUAN}

Sel stem mesenkima (MSC) merupakan sel yang berupaya untuk memperbaharui diri dan membeza kepada pelbagai jenis sel. Selain itu, MSC didapati tidak mempunyai sebarang kontroversi etika berbanding dengan sel stem embrio (Wei et al. 2013; Yildirim et al. 2016). MSC ditakrifkan sebagai sel multipoten yang melekat pada permukaan plastik kelalang pengkulturan serta menunjukkan ciri morfologi yang berbentuk gelendong menyerupai sel fibroblas.
MSC juga didapati mengekspreskan antigen permukaan sel yang khusus serta secara in vitro berupaya untuk membeza kepada sel adiposit, kondrosit dan osteoblas (Liu et al. 2015). Sel stem sumsum tulang (BMSC) dan sel stem adipos (ASC) merupakan sumber MSC yang paling mudah diperoleh kerana mempunyai jumlah sel stem yang banyak. Namun begitu, BMSC menunjukkan tahap komitmen yang lebih tinggi untuk membeza kepada asalan kondrogenik dan osteogenik yang menjadikan BMSC lebih 
baik berbanding ACS (Elkhenany et al. 2016; Xu et al. 2017). Walaupun BMSC telah dikaji dengan lebih terperinci, namun disebabkan oleh faktor kesan morbiditi kepada penderma, kesukaran memperoleh sel yang mencukupi dan kehilangan fenotip sel semasa pengkulturan menyebabkan sumber alternatif bagi sel stem daripada sumber organ dan tisu yang lain diperlukan seperti darah periferi (Muhammad Dain et al. 2011; Ruzanna et al. 2012; Shahrul Hisham et al. 2010). Oleh itu, dalam kajian ini MSC daripada sumber baru iaitu daripada tisu pulpa gigi juga memerlukan kajian lanjut.

Sel stem pulpa gigi berupaya menunjukkan ciriciri BMSC dengan kebolehannya untuk mengekspreskan penanda permukaan dan protein matriks sel yang berkaitan dengan pembentukan tisu mineral seperti alkalin fosfatase, osteokalsin dan osteopontin (Abdallah et al. 2016; Nuti et al. 2016). Tidak seperti tulang, tisu yang terdapat pada gigi tidak mengalami pembentukan semula secara berterusan menunjukkan sel ini lebih komited daripada segi potensi pembezaan sel berbanding BMSC (Nuti et al. 2016; Rohaya et al. 2017). Oleh itu, sumber alternatif bagi sel stem daripada pulpa gigi memerlukan kajian lanjut daripada segi pendekatan pemencilan, pencirian dan potensi osteogeniknya berdasarkan kepada sifat yang terdapat pada MSC daripada sumsum tulang.

Tisu lembut tanpa mineral yang terletak di dalam gigi yang dikenali sebagai tisu pulpa gigi merupakan sumber MSC dewasa yang boleh diperoleh secara tidak invasif dan berpotensi besar untuk digunakan dalam terapi sel. Kebiasaannya, tisu pulpa daripada gigi kekal yang dicabut bagi tujuan rawatan ortodontik atau gigi desiduos yang tertanggal secara semula jadi diambil untuk mendapatkan sel stem bagi tujuan perubatan regeneratif. Tambahan pula, Gronthos et al. (2000) buat pertama kalinya telah berjaya mengasingkan sel stem daripada pulpa gigi manusia yang diperoleh daripada gigi geraham ketiga dan telah menunjukkan bahawa ciri-ciri sel yang dipencilkan itu mempunyai potensi klonogenik, sangat proliferatif dan mampu menghasilkan semula tisu baharu yang jelas menunjukkan cirinya sebagai sel stem. Tiga tahun kemudian, Miura et al. (2003) melaporkan potensi sel stem daripada gigi desiduos manusia mampu untuk menjana semula tulang baru serta mencukupi apabila dipindahkan kepada tikus. Kedua-dua kajian ini merupakan kejayaan awal yang menunjukkan bahawa pulpa gigi daripada gigi kekal dan gigi desiduos adalah calon terbaik untuk menjadi sumber alternatif bagi MSC dewasa yang bersifat multipoten.

Pemahaman tentang pencirian dan mengenal pasti potensi osteogenik sel stem pulpa gigi adalah penting untuk kegunaan masa hadapan, terutamanya bagi aplikasi in vivo dan klinikal untuk pendekatan perubatan regeneratif yang melibatkan sel stem. Oleh itu, dalam kajian ini, pemencilan pulpa gigi daripada dua sumber tisu gigi yang berbeza iaitu tisu pulpa daripada gigi kekal dan gigi desiduos manusia telah dilakukan untuk menentukan perbezaan kedua-dua sel ini daripada segi morfologi, proliferasi dan potensi pembezaan osteoblas.

\section{BAHAN DAN KAEDAH}

\section{PENSAMPELAN GIGI KEKAL DAN DESIDUOS}

Pemencilan sampel daripada sumber gigi manusia bagi kajian ini telah mendapat kelulusan daripada Jawatankuasa Etika Penyelidikan Universiti Kebangsaan Malaysia (nombor kelulusan Etika, UKM PPI/111/8/JEP-2016-524). Gigi kekal dan gigi desiduos yang sihat secara klinikal diperoleh dengan persetujuan subjek (orang dewasa berumur 18-30 tahun untuk gigi kekal) atau persetujuan ibu bapa subjek (ibu bapa kanak-kanak berumur 3-12 tahun untuk gigi desiduos) serta memenuhi semua kriteria bagi pensampelan kajian ini. Sebanyak 10 orang subjek telah terlibat didalam kajian ini yang terdiri daripada lima orang subjek dewasa bagi pensampelan gigi kekal $(n=5)$ dan lima orang subjek kanak-kanak bagi pensampelan gigi desiduos $(n=5)$. Cabutan gigi dilakukan oleh pegawai atau pakar pergigian di Fakulti Pergigian, Universiti Kebangsaan Malaysia, Kuala Lumpur dan Pusat Perubatan Universiti Kebangsaan Malaysia, Cheras, Kuala Lumpur.

\section{PEMENCILAN DAN PENGKULTURAN DPSC DAN SHED}

Tisu pulpa gigi dipotong menjadi serpihan kecil menggunakan skalpel steril dan seterusnya dicernakan dengan $3 \mathrm{mg} / \mathrm{mL}$ kolagenase $1 \mathrm{~A}$ (Sigma, USA) di dalam Knockout Dulbecco Modified Eagle Medium (KO-DMEM) pada suhu $37^{\circ} \mathrm{C}$ selama $40 \mathrm{~min}$ dan divorteks pada setiap 15 min untuk mempercepatkan proses pencernaan. Selepas 40 min, tindak balas enzim dihentikan melalui penambahan $10 \%$ (i/i) serum fetus lembu (FBS) (Gibco, Grand Island, NY, USA). Sel yang berjaya dipencilkan, dikulturkan dalam medium lengkap pengkulturan yang terdiri daripada KODMEM, $10 \%$ (i/i) FBS, $1 \%$ (i/i) penisilin-streptomisin (HI Media, Mumbai, India) dan 0.01x Glutamax (Gibco, Grand Island, NY, USA) di dalam kelalang kultur T75 $\mathrm{cm}^{2}$ serta dieram pada suhu $37^{\circ} \mathrm{C}$ dengan $95 \%$ (i/i) kelembapan dan $5 \%$ (i/i) $\mathrm{CO}_{2}$. Medium lengkap ditukar setelah pengkulturan selama 24 jam dilakukan untuk membuang sel yang tidak melekat. Pertukaran medium lengkap ini dilakukan setiap tiga hari sehingga populasi sel mencapai 80-90\% konfluensi.

\section{PENGASAIAN PROLIFERASI BAGI DPSC DAN SHED}

Keupayaan DPSC dan SHED untuk berproliferasi secara in vitro dianalisis menggunakan pengasaian tiazolil biru tetrazolium bromida (MTT). Sel yang telah konfluen ditanggalkan daripada permukaan kelalang menggunakan $0.25 \%$ (i/i) Tripsin-EDTA (Gibco, Grand Island, NY, USA) dan bilangan sel hidup ditentukan menggunakan hemositometer. Sel kemudiannya dikulturkan pada ketumpatan $1 \times 10^{4} \mathrm{sel} / \mathrm{cm}^{2}$ di dalam plat 96 telaga untuk dianalisis selama 21 hari (hari 0,3, 6, 9, 12, 15, 18 dan 21). Larutan MTT dan media lengkap (nisbah 1:9) ditambahkan ke dalam setiap telaga yang mengandungi sel dan dieram pada suhu $37^{\circ} \mathrm{C}$ selama 4 jam. Kristal Formazan yang terbentuk hasil daripada metabolisme sel dilarutkan di 
dalam dimetilsulfoksida (DMSO) dengan penimbal glisina (glisina 0.1M, NaCl 0.1M, pH10.5) (Sigma, USA). Bacaan ketumpatan optik ditentukan menggunakan Pembaca Mikrotiter Plat ELISA (Bio-Rad, USA) pada panjang gelombang $570 \mathrm{~nm}$. Profil proliferasi sel ditentukan melalui pembinaan graf bilangan sel hidup diplotkan melawan hari analisis.

\section{PEMBEZAAN DPSC DAN SHED KEPADA OSTEOBLAS}

Sebanyak $5 \times 10^{3} \mathrm{sel} / \mathrm{cm}^{2}$ DPSC dan SHED dikulturkan dalam plat 96 telaga serta dieram selama 24 jam pada suhu $37^{\circ} \mathrm{C}$ dengan $95 \%$ (i/i) kelembapan dan 5\% (i/i) $\mathrm{CO}_{2}$. Selepas 24 jam pengeraman, medium lengkap dikeluarkan dan digantikan dengan medium pembezaan osteoblas yang terdiri daripada medium lengkap dengan penambahan 50 $\mathrm{mg} / \mathrm{mL}$ asid askorbik dan $10 \mathrm{mM} \beta$-gliserofosfat. Selain itu, sel yang dikulturkan di dalam medium lengkap tanpa faktor pembezaan akan digunakan sebagai kawalan negatif. Medium lengkap pengkulturan dan pembezaan ditukar dengan medium baru setiap tiga hari.

\section{PENGASAIAN ALKALI FOSFATASE BAGI SEL OSTEOBLAS}

Pengasaian biokimia yang dilakukan melibatkan pengasaian alkalin fosfatase (ALP). Pengasaian ALP dilakukan ke atas DPSC dan SHED yang telah dikulturkan di dalam medium pembezaan sel osteoblas pada hari $0,3,6,9,12,15,18$ dan 21. Setiap sampel sel dibilas dengan menggunakan salin penimbal Tris $(50 \mathrm{mM}$ tris, $150 \mathrm{mM} \mathrm{NaCl}$ ) (TBS) dan diikuti dengan penimbal lisis yang terdiri daripada $0.1 \%$ (i/i) Triton-X 100 (Sigma, USA) TBS sejuk dimasukkan pada setiap telaga. Lisat sel yang terhasil dibeku-cairkan sebanyak tiga kali serta diempar pada kelajuan $8000 \mathrm{~g}$ dengan suhu $4^{\circ} \mathrm{C}$ selama 10 min bagi mendapatkan supernatan. Pengasaian ALP dilakukan melalui pengeraman supernatan ini selama 30 min pada suhu $37^{\circ} \mathrm{C}$ dengan kehadiran $0.1 \mathrm{M}$ penimbal natrium bikarbonat-natrium karbonat (pH10.0) (MERCK, Jerman) yang mengandungi $0.1 \%$ (i/i) Triton X-100, 2 $\mathrm{mM}$ magnesium sulfat (Hamburg Chemicals, Germany) serta substrat $6 \mathrm{mM}$-NPP (4-nitrofenil fosfat disodium heksahidrat), (Sigma, USA). Tindak balas enzim-substrat dihentikan dengan penambahan $1 \mathrm{M}$ natrium hidroksida. Pengukuran ketumpatan optik diambil pada panjang gelombang $405 \mathrm{~nm}$ dengan menggunakan alat Pembaca Mikrotiter Plat ELISA (Bio-Rad, USA). Aktiviti khusus ALP (U/mg) diperoleh dengan membahagikan unit aktiviti enzim (U) dengan jumlah kandungan protein (mg). Jumlah kandungan protein pula ditentukan dengan menggunakan pengasaian Bradford.

\section{ANALISIS STATISTIK}

Hasil yang diperoleh ditunjukkan sebagai min \pm sisihan piawai daripada uji kaji yang telah diulang menggunakan lima batang gigi kekal dan gigi desiduos $(n=5)$ sebagai replikat biologi manakala penentuan aktiviti khusus diulang sebanyak tiga kali untuk mewakili replikat teknikal. Perbezaan signifikan ditentukan menggunakan ujian $t$ dengan nilai $p$ kurang daripada 0.05 dianggap sebagai signifikan.

\section{HASIL PENYELIDIKAN}

\section{PENCIRIAN MORFOLOGI SEL}

Pencirian morfologi DPSC dan SHED ditentukan melalui perisian CellB. Rajah 1 menunjukkan kedua-dua jenis sel berada pada pelbagai tahap konfluensi. DPSC dan SHED yang berjaya dipencilkan pada awal pengkulturan didapati berupaya untuk membentuk koloni serta mempunyai morfologi sel yang menyerupai fibroblas, epitelium dan endothelial (Rajah 1A dan 1D). Selepas 4-5 minggu pemencilan (pengkulturan awal), keduadua jenis sel berjaya mencapai 80-90\% konfluensi yang menjadikannya perlu untuk disubkultur menggunakan tripsin pada kepekatan $0.25 \%$. Sel seterusnya dipindahkan ke dalam media lengkap serta kelalang pengkulturan yang baru (Rajah 1C dan 1F). Kedua-dua jenis sel ini didapati berupaya mengekalkan morfologinya iaitu sel yang menyerupai fibroblas sehingga konfluensi pada pasaj 3. Populasi sel pada pasaj 3 seterusnya digunakan untuk analisis proliferasi dan pembezaan osteoblas.

\section{ANALISIS PROLIFERASI BAGI DPSC DAN SHED}

Analisis proliferasi dilakukan melibatkan populasi sel pasaj 3 melalui pengasaian MTT selama 21 hari. Analisis statistik dijalankan menggunakan ujian $t$ untuk membandingkan perbezaan potensi proliferasi bagi DPSC dengan SHED $(n=5)$ dari hari 0 hingga 21. Hasil analisis menunjukkan bahawa populasi DPSC dan SHED yang dipencilkan mampu untuk berproliferasi secara in vitro. Walau bagaimanapun, keupayaan proliferasi bagi populasi SHED adalah lebih tinggi berbanding dengan DPSC dan didapati lebih ketara lagi pada hari ke 3, 6, 12 dan 18 $(p<0.05, n=5)($ Rajah 2).

\section{PEMBEZAAN OSTEOBLAS BAGI DPSC DAN SHED}

Pengasaian enzim alkalin fosfatase (ALP) dilakukan untuk menilai keupayaan populasi DPSC dan SHED membeza kepada sel osteoblas. Perbandingan terhadap aktiviti enzim ALP antara populasi DPSC dengan SHED serta melibatkan penambahan faktor pembezaan osteoblas (medium pembezaan osteoblas) pada hari 0 sebagai kawalan berbanding dengan populasi sel yang dikulturkan di dalam medium pembezaan osteoblas selama 3-21 hari dilakukan. Aktiviti ALP yang merupakan penanda sel osteoblas menunjukkan populasi DPSC dan SHED berupaya untuk membeza kepada sel osteoblas sepanjang analisis selama 21 hari. Namun begitu, SHED menunjukkan peningkatan yang lebih signifikan berbanding DPSC $(p<0.05, n=5)$ terhadap keupayaan pembezaan kepada osteoblas pada hari ke 9, 12, 15 dan 18 (Rajah 3). 


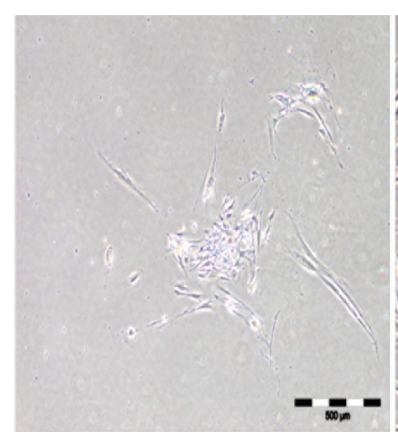

(A)

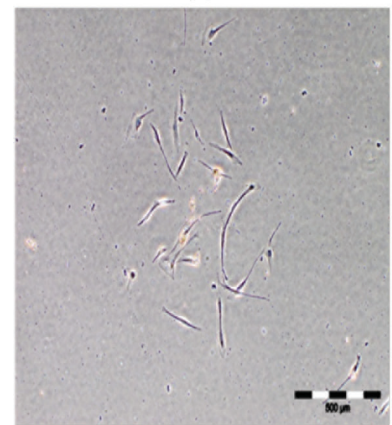

(D)

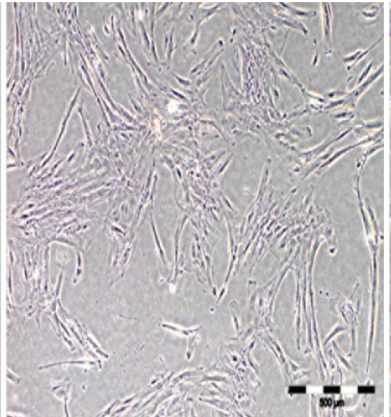

(B)

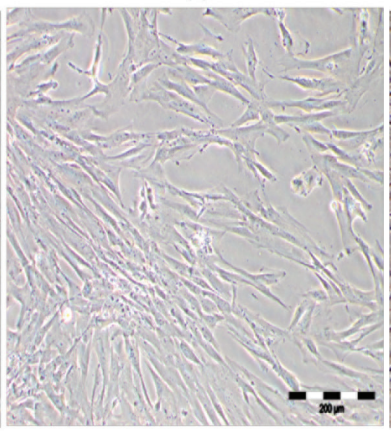

(E)

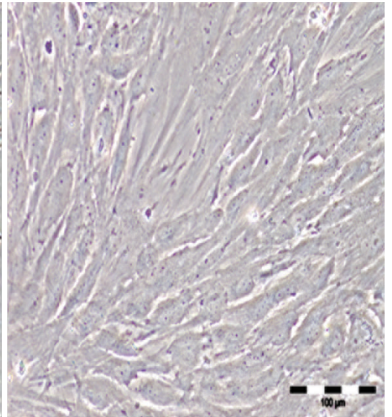

(C)

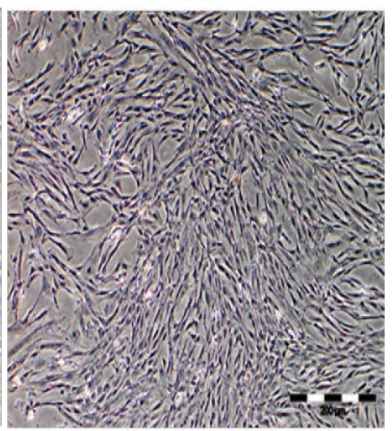

(F)

RAJAH 1. Morfologi DPSC dan SHED mewakili pasaj pertama sehingga konfluensi daripada 5 sampel berlainan ( $n=5$ ). (A) Pembentukan koloni sel DPSC pada minggu pertama selepas pemencilan. (B) DPSC kelihatan hampir konfluen pada hari ke 16 pengkulturan. (C) DPSC menjadi konfluen selepas minggu ke 5 pengkulturan. (D) Pembentukan koloni sel bagi SHED pada minggu pertama selepas pemencilan. (E) SHED kelihatan hampir konfluen selepas 16 hari pengkulturan. (F) SHED menjadi konfluen 4 minggu selepas pemencilan. Populasi sel yang heterogenus kelihatan pada awal pengkulturan (pasaj 0), namun kedua-dua jenis sel menjadi lebih homogenus dan menunjukkan morfologi menyerupai fibroblas apabila mendekati konfluensi selari dengan peningkatan pasaj (pasaj 3)

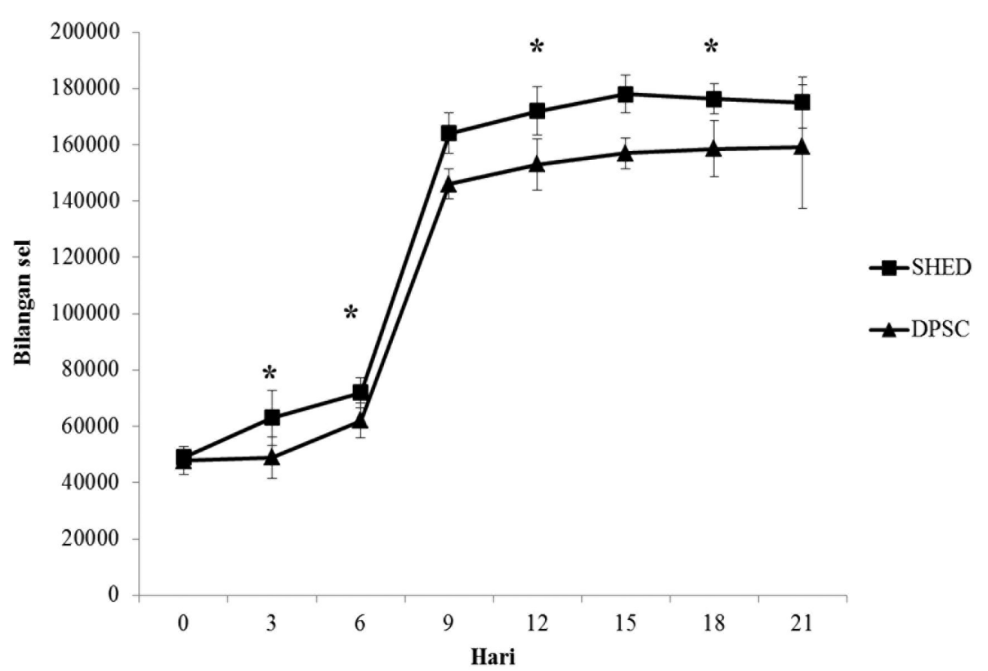

RAJAH 2. Lengkuk pertumbuhan bagi DPSC dan SHED. Keupayaan proliferasi antara DPSC dan SHED dinilai mengunakan pengasaian MTT. Kedua-dua jenis sel dikulturkan dalam medium lengkap selama 21 hari dan pengasaian MTT dilakukan selang tiga hari. Peningkatan signifikan (*) bilangan sel antara DPSC dengan SHED berlaku pada hari ke 3, 6, 12 dan 18.

Nilai yang diplot merupakan purata bilangan sel \pm sisihan piawai $(p<0.05, n=5)$

\section{PERBINCANGAN}

Ketersediaan sumber adalah salah satu kriteria utama dalam pemilihan sebagai sumber alternatif bagi sel stem dewasa. Gigi kekal dan gigi desiduos merupakan dua sumber sel stem mesenkima dewasa yang mudah diperoleh. Gigi kekal dan gigi desiduos digunakan untuk mendapatkan populasi DPSC dan SHED masing-masing mempunyai kelebihan berbanding sumber sel stem dewasa yang lain kerana ia mudah didapati serta boleh diperoleh sepanjang hayat manusia atau disimpan bagi kegunaan masa hadapan. 


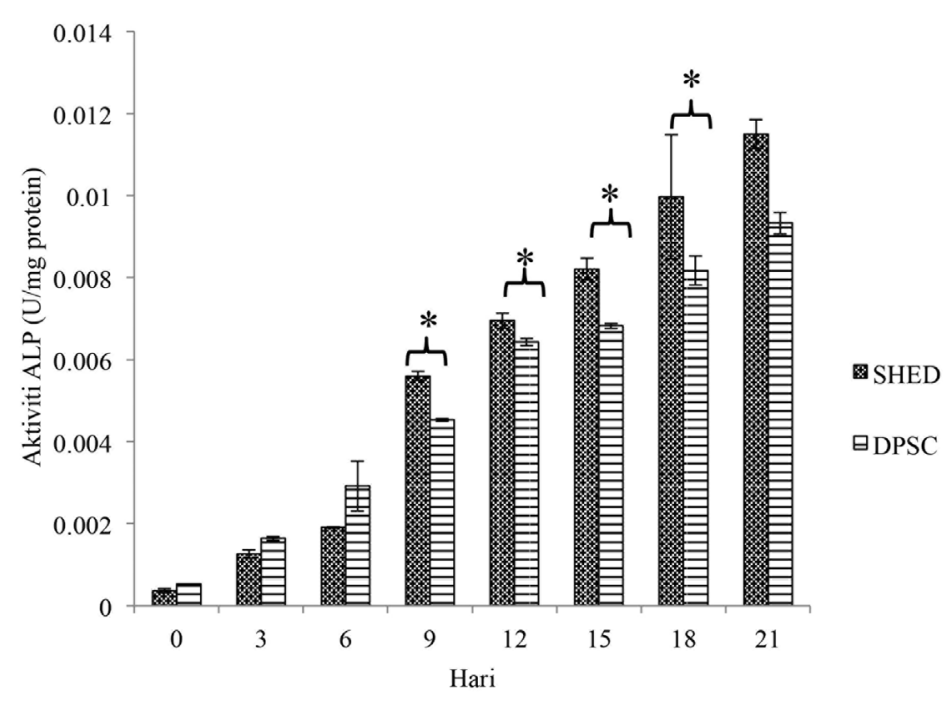

RAJAH 3. Profil aktiviti khusus alkalin fosfatase (ALP) bagi DPSC dan SHED yang dikulturkan dalam medium pembezaan osteoblas. Perbandingan antara DPSC dengan SHED yang telah membeza kepada sel osteoblas menunjukkan perbezaan signifikan (*) pada hari ke 9,12, 15 dan 18. Analisis statistik bagi perbandingan aktiviti ALP antara DPSC dengan SHED selama 21 hari analisis dilakukan menggunakan ujian $t$ berpasangan. Nilai yang diplot merupakan purata aktiviti $\operatorname{ALP} \pm$ sisihan piawai $(p<0.05, n=5)$

Kedua-dua jenis gigi ini boleh didapati daripada penderma yang mengalami hanya pengalaman trauma yang minimum. Kebanyakan penyelidikan mengenai pemencilan sel stem pulpa gigi telah dijalankan menggunakan rawatan enzim pada tisu pulpa daripada pelbagai jenis enzim bertujuan untuk memecahkan matriks ekstrasel dalam tempoh yang singkat bagi mendapatkan ampaian sel tunggal (Akmal et al. 2014). Sebagai contoh, de Souza et al. (2015) telah menggunakan kaedah penglibatan enzim yang berbeza iaitu kolagenase, dispase, tripsin atau kombinasinya untuk mencernakan tisu pulpa gigi.

Berdasarkan kajian ini, didapati bahawa pendekatan pencernaan enzim pada tisu pulpa gigi menggunakan kolagenase $1 \mathrm{~A}$ berupaya menghasilkan populasi sel yang heterogenus. Dalam tempoh satu minggu selepas pengasingan, DPSC dan SHED mampu membentuk koloni yang mengandungi sel seperti fibroblas, epitelium dan endothelial. Ia adalah konsisten dengan kajian Huang et al. (2006) yang menyatakan bahawa masa yang diperlukan bagi sel stem pulpa gigi untuk membentuk koloni mungkin berbeza dari satu hingga dua minggu selepas pengkulturan. BMSC yang dikenal pasti sebagai piawai bagi MSC pula turut memerlukan masa sekitar satu minggu bagi pembentukan koloni sel yang berbentuk fibroblas dan mencapai konfluensi selepas 25 hari pengkulturan (Neto et al. 2016). Tempoh masa yang diambil oleh DPSC dan SHED untuk menjadi konfluen adalah selama 4 hingga 5 minggu iaitu tempoh masa yang hampir sama diperlukan oleh populasi BMSC untuk mencapai konfluensi. Selepas minggu pertama pengkulturan, kedua-dua jenis sel akan memanjang bagi menandakan bermulanya pembentukan morfologi sel yang menyerupai fibroblas dan seterusnya bertukar menjadi fibroblas sepenuhnya pada minggu kedua. Walaupun gigi kekal berbeza berbanding gigi desiduos daripada segi proses perkembangan, struktur tisu dan fungsi; namun kedua-dua jenis sel stem pulpa gigi yang dipencilkan dalam kajian ini berupaya untuk melekat pada permukaan plastik kelalang pengkulturan. Populasi DPSC dan SHED semasa pemerhatian secara makroskopik akan menunjukkan morfologi sel yang sama iaitu menyerupai sel fibroblas. Morfologi sel yang menyerupai sel fibroblas ini merupakan ciri utama untuk sel stem mesenkima seperti yang telah dinyatakan oleh International Society of Cellular Therapy (ISCT). Ciri morfologi ini juga turut ditunjukkan oleh BMSC semasa pengkulturan in vitro (Dominici et al. 2006; Miura et al. 2003; Mushegyan et al. 2014).

Dalam kajian ini, perbandingan keupayaan proliferasi antara DPSC dengan SHED dianalisis selama 21 hari pengkulturan menggunakan pengasaian tiazolil biru tetrazolium bromida (MTT). Selain pengasaian MTT, keupayaan proliferasi sel juga boleh ditentukan menggunakan pendekatan pewarnaan tripan biru. Kajian melibatkan pendekatan MTT dan pewarnaan tripan biru menunjukkan ekstrak etanol Piper sarmentosum berupaya untuk merencat proliferasi titisan sel hati iaitu sel HepG2 dan sel Chang (Shahrul Hisham et al. 2009; Wan Haifa et al. 2010). Kedua-dua jenis sel stem pulpa gigi yang diasingkan didapati mampu untuk membentuk koloni dengan keupayaan proliferasi yang tinggi. Walau bagaimanapun, sel stem yang diasingkan daripada tisu pulpa gigi desiduos menunjukkan keupayaan proliferasi yang lebih tinggi berbanding dengan sel stem daripada tisu pulpa gigi kekal apabila dikulturkan dalam medium lengkap pengkulturan. Kajian terdahulu oleh Miura et al. (2003) dan Tatullo et al. (2015) juga memperlihatkan bahawa proliferasi SHED adalah jauh lebih tinggi daripada DPSC. Keupayaan SHED untuk berproliferasi pada kadar yang tinggi berbanding DPSC berkemungkinan disebabkan 
oleh peningkatan faktor umur iaitu proses penuaan. Kajian oleh Ma et al. (2009) pada sel stem pulpa gigi tikus menunjukkan berlakunya peningkatan proliferasi pada sel stem yang dipencilkan daripada tisu pulpa gigi anak tikus berbanding tikus dewasa. Kajian lain oleh Mitsiadis dan De Bari (2008) menunjukkan penurunan isi padu dan ruang pulpa gigi adalah selari dengan proses penuaan disebabkan penghasilan matriks dentin oleh sel odontoblas yang menyebabkan pemendapan kalsium meningkat pada ruang pulpa. Penurunan isi padu pulpa gigi ini berkemungkinan menyebabkan penurunan kepada jumlah sel yang boleh dipencilkan daripada gigi kekal dewasa berbanding tisu pulpa gigi desiduos kanak-kanak. Hasil yang diperoleh daripada kajian ini juga menunjukkan bahawa SHED mempunyai kemampuan proliferasi sel yang lebih tinggi berbanding DPSC seperti yang telah ditunjukkan oleh Miura et al. (2003) dan Tatullo et al. (2015).

Dalam kajian ini, potensi pembezaan osteoblas bagi populasi DPSC dan SHED juga dianalisis menggunakan pendekatan pengasaian enzim alkali fosfatase (ALP). Kebiasaannya, ALP diekspreskan secara khusus di dalam pelbagai jenis sel dan tisu dewasa seperti sel progenitor saraf, sel pulpa gigi manusia dan sel stem mesenkima daripada sumsum tulang (Stefkova et al. 2015; Tomlinson et al. 2015). ALP juga boleh bertindak sebagai penanda biologi bagi pembentukan tulang melalui proses pemineralan pada tisu dengan membekalkan fosfat semasa pembentukan kristal hidroksiapatit serta menghidrolisis molekul pirofosfat. Semasa proses penjanaan semula tisu tulang, molekul pirofosfat perlu dihidrolisiskan kerana molekul ini merupakan perencat bagi proses pembentukan matriks tulang (Farinawati et al. 2018; Kermani et al. 2014; Štefková et al. 2015). Walaupun ALP masih dihasilkan oleh sel pada kadar biasa, penambahan faktor perbezaan osteoblas sewaktu pengkulturan secara in vitro telah menyebabkan peningkatan terhadap profil aktiviti enzim ALP. Menjadikan ALP sebagai penanda biologi yang sesuai dalam pencirian osteogenik untuk sel stem pulpa gigi (Birmingham et al. 2012). Štefková et al. (2015) juga menekankan wujudnya hubungan antara aktiviti ALP dengan pengekspresan dan pengawalaturannya yang dikawal oleh persekitaran mikro pada sel dan bukannya oleh tapak jalan pengisyaratan sel. Oleh itu, profil aktiviti ALP dikawal oleh status perkembangan sel yang menjadikannya sesuai sebagai penanda biologi untuk menentukan tahap pembezaan sel osteoblas semasa pengkulturan sel secara in vitro atau in vivo. Dalam kajian ini, DPSC dan SHED yang telah berjaya dipencilkan mempunyai keupayaan untuk membeza kepada osteoblas. Analisis aktiviti ALP bagi kedua-dua jenis sel ini menunjukkan perbezaan yang signifikan $(p<0.05)$ berlaku pada sel yang dikulturkan di dalam media pembezaan osteoblas pada hari $3,6,9,12,15,18$ dan 21 berbanding dengan kumpulan kawalan (sel dikultur pada hari 0 ). Selain itu, apabila DPSC dan SHED diaruh untuk membeza kepada osteoblas menggunakan faktor pembezaan yang terdiri daripada asid askorbik dan $\beta$-gliserofosfat, SHED menunjukkan kebolehan pembezaan osteoblas yang lebih tinggi berbanding DPSC dengan perbezaan yang signifikan $(p<0.05)$ pada hari ke $9,12,15$ dan 18 . SHED mempunyai aktiviti ALP yang lebih tinggi berbanding DPSC disebabkan oleh keupayaan osteoinduktifnya yang lebih baik. Ini berlaku kerana SHED merupakan populasi sel yang kurang matang berbanding DPSC, maka mempunyai keupayaan yang lebih tinggi untuk membentuk sel osteoblas (Huang et al. 2009; Miura et al. 2003). Kajian oleh Nourbakhsh et al. (2008), Raouf dan Seth (2002) serta Thomas et al. (2002) mencadangkan peningkatan aktiviti ALP untuk sel stem gigi kebanyakannya berlaku antara 11 hingga 25 hari selepas rangsangan kepada osteoblas. Malah, keupayaan MSC dewasa lain seperti BMSC untuk membeza kepada osteoblas juga bermula pada hari ke-11 dan meningkat sehingga hari ke-18 pengkulturan di dalam media pembezaan sel osteoblas (Neto et al. 2016). Hasil yang diperoleh daripada kajian awal oleh beberapa penyelidik ini adalah selari dengan hasil yang diperoleh dalam kajian ini, iaitu pembezaan DPSC dan SHED kepada sel osteoblas bermula pada hari ke 9 hingga 21 pengkulturan. Hal ini menunjukkan bahawa DPSC dan SHED menjalani pembezaan kepada sel osteoblas pada tempoh masa yang lebih lama tetapi menghasilkan aktiviti osteoblas yang lebih baik berbanding BMSC. Hasil kajian oleh Jensen et al. (2016) juga menunjukkan bahawa sel stem pulpa gigi mempunyai aktiviti ALP dan pemendapan kalsium yang lebih tinggi berbanding BMSC semasa pengkulturan secara in vitro. Hal ini menjadikan DPSC dan SHED sebagai sumber sel stem yang terbaik bagi menggantikan BMSC dalam penjanaan semula tulang. Selain itu, DPSC dan SHED juga didapati berpotensi untuk membeza kepada sel odontoblas (Paduano et al. 2016), neuron (Sanen et al. 2017), kondrosit (Yao \& Flynn 2018) dan adiposit (Davies et al. 2015) yang berpotensi untuk digunakan dalam merawat penyakit Alzheimer, osteoartritis, osteoporosis, luka pada kulit serta masalah pergigian (Potdar \& Jethmalani 2015; Ude et al. 2018).

\section{KESIMPULAN}

Pencirian dan potensi pembezaan osteogenik oleh sel stem pulpa gigi kekal (DPSC) dan sel stem pulpa gigi desiduos (SHED) adalah penting kerana kedua-dua jenis sel stem ini diperoleh daripada sumber yang berlainan iaitu DPSC diperoleh daripada gigi kekal dan SHED daripada gigi desiduos manusia. Kedua-dua sumber ini mempunyai proses perkembangan, struktur tisu dan fungsi berbeza yang berkemungkinan mempunyai keupayaan proliferasi dan potensi pembezaan osteogenik yang berbeza. Hasil daripada kajian ini mendapati populasi DPSC dan SHED berupaya untuk berproliferasi dan membeza kepada sel osteoblas. Keupayaan DPSC dan SHED untuk membentuk koloni, mempamerkan morfologi yang menyerupai fibroblas, berupaya untuk berproliferasi dan membeza kepada sel osteoblas menjadikannya sebagai sumber alternatif bagi MSC dewasa untuk menggantikan populasi BMSC. Oleh itu, sel DPSC dan SHED berpotensi untuk digunakan sebagai sumber alternatif dalam terapi 
penjanaan tulang. Data yang diperoleh daripada kajian ini juga mendapati SHED mempunyai keupayaan proliferasi dan potensi osteogenik yang lebih baik berbanding DPSC. Walaupun begitu, kajian lanjut perlu dilakukan untuk menilai kualiti penjanaan tulang antara DPSC dan SHED seperti analisis melibatkan pengkulturan 3-Dimensi menggunakan perancah pada peringkat in vitro dan in vivo.

\section{PENGHARGAAN}

Setinggi-tinggi penghargaan ditujukan kepada Universiti Kebangsaan Malaysia dan Kementerian Pengajian Tinggi Malaysia atas tajaan bagi menjalankan penyelidikan ini di bawah Skim Geran Penyelidikan Fundamental (FRGS), FRGS/1/2015/SG05/UKM/02/2.

\section{RUJUKAN}

Abdallah, B.M., Al-Shammary, A., Khattab, H.M., Al Dahmash, A. \& Kassem, M. 2016. Bone marrow stromal stem cells for bone repair: Basic and translational aspects. Dlm. Recent Advances in Stem Cells, edited by Abdelalim, E. Switzerland: Springer. hlm. 213-232.

Akmal, M.N., Zarina, Z.I., Rohaya, M., Sahidan, S., Zaidah, Z. \& Hisham, Z.S. 2014. Isolation and characterization of dental pulp stem cells from murine incisors. Journal of Biological Sciences 14(4): 327-331.

Birmingham, E., Niebur, G. \& McHugh, P. 2012. Osteogenic differentiation of mesenchymal stem cells is regulated by osteocyte and osteoblast cells in a simplified bone niche. European Cells and Materials 23: 13-27.

Davies, O., Cooper, P., Shelton, R., Smith,A.\& Scheven, B. 2015. A comparison of the in vitro mineralisation and dentinogenic potential of mesenchymal stem cells derived from adipose tissue, bone marrow and dental pulp. Journal of Bone and Mineral Metabolism 33(4): 371-382.

de Souza, L.M., Bittar, J.D., da Silva, I.C.R., de Toledo, O.A., de Macedo Brígido, M. \& Fonseca, M.J.P. 2015. Comparative isolation protocols and characterization of stem cells from human primary and permanent teeth pulp. Brazilian Journal of Oral Sciences 9(4): 427-433.

Dominici, M., Le Blanc, K., Mueller, I., Slaper-Cortenbach, I., Marini, F., Krause, D., Deans, R., Keating, A., Prockop, D . \& Horwitz, E. 2006. Minimal criteria for defining multipotent mesenchymal stromal cells. The International Society for cellular therapy position statement. Cytotherapy 8(4): 315317.

Elkhenany, H., Amelse, L., Caldwell, M., Abdelwahed, R. \& Dhar, M. 2016. Impact of the source and serial passaging of goat mesenchymal stem cells on osteogenic differentiation potential: Implications for bone tissue engineering. Journal of Animal Science and Biotechnology 7(1): 16.

Farinawati Yazid, Nur Atmaliya Luchman, Rohaya Megat Abdul Wahab, Shahrul Hisham Zainal Abidin \& Sahidan Senafi 2018. Proliferation and osteoblast differentiation mice dental pulp stem cells between enzyme digestion and outgrowth method. Sains Malaysiana 47(4): 691-698.

Gronthos, S., Mankani, M., Brahim, J., Robey, P.G. \& Shi, S. 2000. Postnatal human dental pulp stem cells (DPSCs) in vitro and in vivo. Proceedings of the National Academy of Sciences 97(25): 13625-13630.
Huang, G.J., Gronthos, S. \& Shi, S. 2009. Mesenchymal stem cells derived from dental tissues vs. those from other sources: Their biology and role in regenerative medicine. Journal of Dental Research 88(9): 792-806.

Huang, G.T.J., Sonoyama, W., Chen, J. \& Park, S.H. 2006. In vitro characterization of human dental pulp cells: Various isolation methods and culturing environments. Cell and Tissue Research 324(2): 225-236.

Jensen, J., Tvedesøe, C., Rölfing, J.H.D., Foldager, C.B., Lysdahl, H., Kraft, D.C.E., Chen, M., Baas, J., Le, D.Q.S. \& Bünger, C.E. 2016. Dental pulp-derived stromal cells exhibit a higher osteogenic potency than bone marrow-derived stromal cells in vitro and in a porcine critical-size bone defect model. Sicot J. 2: 16 .

Kermani, S., Wahab, R.M.A., Abidin, I.Z.Z., Ariffin, Z.Z., Senafi, S. \& Ariffin, S.H.Z. 2014. Differentiation capacity of mouse dental pulp stem cells into osteoblasts and osteoclasts. Cell Journal (Yakhteh) 16(1): 31-42.

Liu, J., Yu, F., Sun, Y., Jiang, B., Zhang, W., Yang, J., Xu, G.T., Liang, A. \& Liu, S. 2015. Concise reviews: Characteristics and potential applications of human dental tissue-derived mesenchymal stem cells. Stem Cells 33(3): 627-638.

Ma, D., Ma, Z., Zhang, X., Wang, W., Yang, Z., Zhang, M., Wu, G., Lu, W., Deng, Z. \& Jin, Y. 2009. Effect of age and extrinsic microenvironment on the proliferation and osteogenic differentiation of rat dental pulp stem cells in vitro. Journal of Endodontics 35(11): 1546-1553.

Mitsiadis, T.A. \& De Bari, C. 2008. Apoptosis in developmental and repair-related human tooth remodeling: A view from the inside. Experimental Cell Research 314(4): 869-877.

Miura, M., Gronthos, S., Zhao, M., Lu, B., Fisher, L.W., Robey, P.G. \& Shi, S. 2003. SHED: Stem cells from human exfoliated deciduous teeth. Proceedings of the National Academy of Sciences 100(10): 5807-5812.

Muhammad Dain, Y., Shahrul Hisham, Z.A., Sahidan, S., Zaidah, Z.A. \& Rohaya, M.A.W. 2011. Stem cell heterogeneity of mononucleated cells from murine peripheral blood: Molecular analysis. The Scientific World Journal 11: 21502159.

Mushegyan, V., Horst, O. \& Klein, O.D. 2014. Adult stem cells in teeth. Dlm. Adult Stem Cells. Springer. hlm. 199-216.

Neto, N.M.A., Feitosa, M.L.T., Sousa, S.S., Fernandes, P.B., Pessoa, G.T., de Oliveira Bezerra, D., de Almeida, H.M., de Carvalho, Y.K.P., da Rocha, A.R. \& Silva, L.M.C. 2016. Isolation, expansion, differentiation and growth kinetics essay in mesenchymal stem cells culture from the bone marrow of collared peccaries (Tayassu tajacu). Acta Scientiae Veterinariae 44: 01-11.

Nourbakhsh, N., Talebi, A., Mousavi, B., Nadali, F., Torabinejad, M., Karbalaie, K. \& Baharvand, H. 2008. Isolation of mesenchymal stem cells from dental pulp of exfoliated human deciduous teeth. Cell J. 10(2): 101-108.

Nuti, N., Corallo, C., Chan, B., Ferrari, M. \& Gerami-Naini, B. 2016. Multipotent differentiation of human dental pulp stem cells: A literature review. Stem Cell Reviews and Reports 12(5): 511-523.

Paduano, F., Marrelli, M., White, L.J., Shakesheff, K.M. \& Tatullo, M. 2016. Odontogenic differentiation of human dental pulp stem cells on hydrogel scaffolds derived from decellularized bone extracellular matrix and collagen type I. PloS ONE 11(2): e0148225.

Potdar, P.D. \& Jethmalani, Y.D. 2015. Human dental pulp stem cells: Applications in future regenerative medicine. World Journal of Stem Cells 7(5): 839-851. 
Raouf, A. \& Seth, A. 2002. Discovery of osteoblast-associated genes using cDNA microarrays. Bone 30(3): 463-471.

Rohaya, M.A.W., Nur Akmal, M.R., Sahidan, S., Intan Zarina, Z.A., Zaidah, Z.A. \& Shahrul Hisham, Z.A. 2017. Impact of isolation method on doubling time and the quality of chondrocyte and osteoblast differentiated from murine dental pulp stem cells. Peer J. 5: e3180.

Ruzanna, A.K., Shahrul Hisham, Z.A., Rohaya, M.A.W., Shabnam, K. \& Sahidan, S. 2012. Characterization of mononucleated human peripheral blood cells. The Scientific World Journal 2012: Article ID. 843843.

Sanen, K., Martens, W., Georgiou, M., Ameloot, M., Lambrichts, I. \& Phillips, J. 2017. Engineered neural tissue with Schwann cell differentiated human dental pulp stem cells: Potential for peripheral nerve repair? Journal of Tissue Engineering and Regenerative Medicine 11(12): 3362-3372.

Shahrul Hisham, Z.A., Intan Zarina, Z.A., Muhammad Dain, Y. \& Rohaya, M.A.W. 2010. Differentiation analyses of adult suspension mononucleated peripheral blood cells of Mus musculus. Cell Communication and Signaling 8(1): 29.

Shahrul Hisham, Z.A., Wan Haifa Haryani, W.O., Zaidah Z.A., Muhd Fauzi, S., Sahidan, S. \& Rohaya, M.A.W. 2009. Intrinsic anticarcinogenic effects of Piper sarmentosum ethanolic extract on a human hepatoma cell line. Cancer Cell International 9: 6.

Štefková, K., Procházková, J. \& Pacherník, J. 2015. Alkaline phosphatase in stem cells. Stem Cells International 2015: 628368 .

Tatullo, M., Marrelli, M., Shakesheff, K.M. \& White, L.J. 2015. Dental pulp stem cells: Function, isolation and applications in regenerative medicine. Journal of Tissue Engineering and Regenerative Medicine 9(11): 1205-1216.

Thomas, C.H., Collier, J.H., Sfeir, C.S. \& Healy, K.E. 2002. Engineering gene expression and protein synthesis by modulation of nuclear shape. Proceedings of the National Academy of Sciences 99(4): 1972-1977.

Ude, C.C., Miskon, A., Idrus, R.B.H. \& Bakar, M.B.A. 2018. Application of stem cells in tissue engineering for defense medicine. Military Medical Research 5(1): 7.

Wan Haifa Haryani, W.O., Shahrul Hisham, Z.A., Muhd Fauzi, S., Sahidan, S. \& Rohaya, M.A.W. 2010. Penyaringan antikanser ekstrak etanol daripada famili piperaceae terpilih dan penentuannya melalui pewarnaan tripan biru. Sains Malaysiana 39(6): 941-949.
Wei, X., Yang, X., Han, Z.P., Qu, F.F., Shao, L. \& Shi, Y.F. 2013. Mesenchymal stem cells: A new trend for cell therapy. Acta Pharmacologica Sinica 34(6): 747-754.

Xu, L., Liu, Y., Sun, Y., Wang, B., Xiong, Y., Lin, W., Wei, Q., Wang, H., He, W. \& Li, G. 2017. Tissue source determines the differentiation potentials of mesenchymal stem cells: A comparative study of human mesenchymal stem cells from bone marrow and adipose tissue. Stem Cell Research \& Therapy 8(1): 275.

Yao, L. \& Flynn, N. 2018. Dental pulp stem cell-derived chondrogenic cells demonstrate differential cell motility in type I and type II collagen hydrogels. The Spine Journal 18(6): 1070-1080.

Yildirim, S., Zibandeh, N., Genc, D., Ozcan, E.M., Goker, K. \& Akkoc, T. 2016. The comparison of the immunologic properties of stem cells isolated from human exfoliated deciduous teeth, dental pulp, and dental follicles. Stem Cells International 2016: Article ID. 4682875.

Farinawati Yazid, Nur Atmaliya Luchman \& Rohaya Megat Abdul Wahab

Pusat Kesihatan Pergigian Keluarga

Fakulti Pergigian

Universiti Kebangsaan Malaysia

50300 Kuala Lumpur, Wilayah Persekutuan

Malaysia

Shahrul Hisham Zainal Ariffin*

Pusat Bioteknologi dan Makanan Berfungsi

Fakulti Sains dan Teknologi

Universiti Kebangsaan Malaysia

43600 Bangi, Selangor Darul Ehsan

Malaysia

*Pengarang untuk surat-menyurat; email: hisham@ukm.edu.my

Diserahkan: 5 Julai 2018

Diterima: 26 April 2019 